\title{
KAJIAN REKAYASA LALULINTAS (PEMBERLAKUAN JALAN SATU ARAH JLN. Dr. WAHIDIN RUAS REMBIGA - GUNUNG SARI) PADA SIMPANG EMPAT REMBIGA KOTA MATARAM
}

\author{
STUDY OF TRAFFIC ENGINEERING (APPLICATION OF ONE-WAY ROAD JLN. Dr. WAHIDIN \\ RUAS REMBIGA - GUNUNG SARI) AT REMBIGA INTERSECTION OF MATARAM CITY
}

\author{
Addinuri $^{*}$, Titik Wahyuningsih ${ }^{2}$, Anwar Efendy ${ }^{3}$ \\ ${ }^{1,2,3}$ Teknik Sipil Fakultas Teknik, Universitas Muhammadiyah Mataram \\ Korespondensi: addijoeng@gmail.com
}

\begin{abstract}
ABSTRAK
Indonesia merupakan salah satu negara yang tengah berkembnag dimana mengalami kasus lebih kompleks dibanding dengan negara maju salah satunya kemacetan lalulintas kerap kita jumpai disebagian kota salah satunya di Kota Mataram mengakibatkan naiknya jumlah pergerakan lalulintas dari berbagai jenis kendaraan, menambah padatnya arus lalulintas simpang dan perlunya manajemen lalulintas yang tepat untuk mengatur kelancara arus lalulintas, bertujuan mengetahui kinerja simpang dan penerapan rekayasa lalulintas sistem satu arah pada Jalan Dr. Wahidin Rembiga - Kota Mataram yang memiliki kemacetan cukup parah dikarnakan lebar ruas jalan yang tidah memadai, merupakan jalan penghubung antar kota dan kabupaten, mengakibatkan naiknya jumlah pergerakan yang beragam dari berbagai jenis kendaraan. Penerapan sistem jalan satu arah sebagai solusi mengatasi kemacetan. Setiap ruas memiliki lebar jalan dan lebar bahu jalan yang berbeda. menggunkan panduan MKJI 1997 (Manual Kapasitas Jalan Indonesia). Faktor utama sebagai parameter penelitian ialah derajat kejenuhan dan tingkat pelayanan ruas. Hasil tingkat kinerja pelayanan sangat terlihat jelas pada ruas Jalan Dr. Wahidin saat kondisi eksisting didapat nilai derajat kejenuhan 1.13 berarti tingkat pelayanan ruas mendapatkan nilai $\mathrm{F}$ diterapkannya sistem satu arah derajat kejenuhan turun menjadi 0.52 tingkat pelayanan berubah menjadi $\mathrm{C}$ dimana sangat berpengaruh pada pelayanan ruas jalan dan mengatasi kemacetan terjadi pada jalan tersebut.
\end{abstract}

Kata Kunci: Sistem satu arah, Tingkat Pelayanan

\begin{abstract}
Indonesia is one of the developing countries where cases are more complex than developed countries, one of which is traffic jams that we often encounter in some cities, one of which is Mataram City, resulting in an increase in the number of traffic movements of various types of vehicles, increasing the density of intersection traffic flows and the need for traffic management. the right way to regulate the smooth flow of traffic, aims to determine the performance of the intersection and the application of one-way traffic engineering on Jalan Dr. Wahidin Rembiga - Mataram City, which has quite severe congestion due to inadequate road width, is a connecting road between cities and regencies, resulting in an increase in the number of diverse movements of various types of vehicles. The application of the one-way road system as a solution to overcome congestion. Each segment has a different road width and shoulder width. using the 1997 MKJI guide (Indonesian Road Capacity Manual). The main factors as research parameters are the degree of saturation and the level of segment service. The results of the level of service performance are very clear on the Jalan Dr. Wahidin when
\end{abstract}


the existing condition obtained a degree of saturation value of 1.13, it means that the service level of the segment gets an $F$ value, the implementation of a one-way system, the degree of saturation drops to 0.52, the level of service changes to $C$ which is very influential on road service and overcomes congestion on the road..

\section{Keywords: One-way system, Service Level}

\section{PENDAHULUAN}

Kasus transpotasi semacam kemacetan, polusi udara, kecelakaan, antrian ataupun tundaaan biasa ditemukan dengan tingkatan mutu yang rendah ataupun tinggi, bersamaan dengan perkembangan ekonomi serta pertambahan populasi yang cukup signifikan. Kasus tersebut kerap kita jumpai di sebagian kota di Indonesia salah satunya di Kota Mataram, kasus ini pula di akibatkan oleh perkembangan kedaraan yang terus meningkat disetiap tahunnya tidak hanya itu jumlah prasarana yang kurang mencukupi dan watak pengemudi yang kurang disiplin.

Kota Mataram sebagai pusat perekonomian di Provinsi Nusa Tenggara Barat yang menghubungkan jalur perdaganggan antar kota kabupaten, mengakibatkan naiknya jumlah pergerakan lalulintas yang beragam dari berbagai jenis kendaraan, sehingga secara tidak langsung menambah padatnya arus lalulintas di Kota Mataram Khususnya di simpang Rembiga dan diperlukannya adanya manajemen lalulintas yang tepat untuk mengatur kelancara arus lalulintas. Pada tahun 2020, jumlah penduduk Kota Mataram dengan jumlah penduduk sebanyak 441.064 jiwa dan total kendaraan di Kota Mataram sebnyak 200.307 unit dan panjang jalan yang ada di Kota Mataram hanya 193,242 km maka kepadatan kendaraan di Kota Mataram mncapa 1036.56 kend/km (Badan Pusat Statitiska Kota Mataram, 2020) kondisi inilah yang mengakibatkan timbulnya kemacetan dan waktu tempuh perjalanan menjadi lebih lama.

Permasalahan pada simpang berupa tundaan yang tinggi serta seringnya terjadi kecelakaan. Pengaturan waktu hentian/ tundaan serta waktu jalan yang dioprasikan saat ini belum bisa menanggulangi kemacetan yang selalu terjadi lebih- lebih pada jam- jam sibuk (peak hour). Keadaan geometrik jalan pada simpang rembiga belum sanggup menampung volume lalulintas yang terkategori padat. Terlebih lagi dengan terdapatnya simpang terdekat dengan jarak $152 \mathrm{~m}$ tanpa sinyal lalulintas. Dengan kondisi semacam ini, kendaraan yang telah melewati simpang kerap sekali tertahan akibat konflik di simpang terdekat, sehingga pada fase hijau selanjutnya masih terjadi antrian kendaraan. Perlunya upaya guna menambah kinerja simpang agar tercapai efisiensi serta kelancaran lalulintas.

Salah satu manajemen lalulintas yang dapat dilakukan guna mengurangi jumlah kemacetan serta kepadatan kendaraan pada titik tertentu ialah melalui penyelesaian sistem jalan satu arah sesuatu pola lalulintas yang dicoba dengan mengubah jalan 2 arah menjadi jalan satu arah yang berfungsi guna menaikkan keselamatan serta kapasitas jalan serta persimpangan sehingga meningkatakan kelancaran lalulintas yang umumnya diterapkan di daerah perkotaan. Dengan diterapkannya perubahan sistem satu arah ini diharapkan dapat mengurangi kemacetan pada jam-jam sibuk yang terjadi di masa mendatang. Agar dapat mengetahui kinerja setelah adanya perubahan pemberlakuan sistem satu arah tersebut, maka perlu dilakuakan penelitian terhadap kinerja arus jalan sebelum dilakukan pemberlakuan sistem satu arah dan setelah pemberlakuan sistem satu arah diterapkan

Tujuan Penelitian tujuan yang ingin dicapai dari penelitian ini ialah:

1. Mengetahui kinerja simpang Rembiga, meliputi: kapasitas, volume, derajat kejenuhan pada kondisi eksisting.

2. Mengetahui perbandingan dan peningkatan kinerja jalan pada saat sebelum dan sesudah adanya penerapan sistem satu arah

\section{TINJAUAN PUSTAKA}

Lalulintas harian rata-rata ialah volume lalulintas dalam satuan hari. Dari cara memdapatkan data tersebut digunakan dua jenis lalulintas harian rata-rata yaitu lalulintas harian rata-rata tahunan (LHRT) dan lalulintas harian rata-rata (LHR) (Sukirman, 1994).

LHRT ialah jumlah lalulintas kendaraan rata-rata yang telah melewati satu jalur jalan selama 24 (dua puluh empat) jam dan diperoleh dari data selama periode satu tahun penuh.

LHR $=\frac{\text { jumlah lalulintas dalam setahun }}{365 \text { (hari) }}$ 
Kajian Rekayasa Lalulintas .., Addinuri( ${ }^{(1)}$, Titik Wahyuningsih ${ }^{(2)}$, Anwar Efendy $^{(3)}$

LHR ialah hasil bagi jumlah kendaraan yang diperoleh selama periode pengamatan yang ditentukan dengan lamanya pengamatan

$$
\mathrm{LHR}=\frac{\text { jumlah lalulintas harian rata-rata }}{\text { lamanya pengamatan }}
$$

\section{Arus Lalulintas Jalan}

Arus lalulintas ialah banyak kendaraan bermotor yang melalui titik tertentu persatuan waktu, dinyatakan dalam kendaraan perjam atau smp/jam. Menurut jenis dan arah pergerakan kendaraan yang melewati titik pengamatan (memasuki persimpangan), jumlah kendaraan dihitung dengan interval waktu 15 menit dengan kondisi arus lalulintas pada jam puncak (pagi, siang dan sore) dan dinyatakan dengan jumlah kendaraan perjam (smp/jam). Arus lalulintas di kawasan perkotaan dibagi menjadi empat (4) (MKJI,1997) jenis yakni:

\section{a. Kendaraan Ringan / Light Vehicle (LV)}

Meliputi kendaraan bermotor 2 as beroda empat dengan jarak as 2,0-3,0 m (termasuk mobil penumpang, mikrobis, pick-up, truk kecil, sesuai sistem klasifikasi Bina Marga).

b. Kendaraan Berat/ Heave Vehicle (HV)

Meliputi kendaraan motor dengan jarak as lebih dari $3,5 \mathrm{~m}$, biasanya beroda lebih dari empat (termasuk bis, truk dua as, truk tiga as, dan truk kombinasi)

c. Kendaraan Berat/Motor Cycle (MC)

Meliputi kendaraan bermotor roda dua atau tiga (termasuk sepeda motor dan kendaraan roda tiga sesuai system klasifikasi Bina Marga)

d. Kendaraan tidak Bermotor/ Un Motorized (UM) Meliputi kendaraan beroda yang menggunakan tenaga manusia, hewan, dan lainnya (termasuk becak, sepeda, kereta kuda, kereta dorong dan lain-lain sesuai system klasifikasi Bina Marga).

Satuan dari setiap jenis kendaraan dengan karakteristik pergerakan yang berbeda, arus lalulintas (Q) dari setiap pergerakan kendaraan \{belok kiri (QLT), belok kanan (QRT) dan lurus (QST) \}. Oleh karena itu, untuk menyeimbangkan dari tiap jenis kendaraan agar keluar dari antrian digunakan ekivalen mobil penumpang (emp) dari masing-masing metode terproteksi dan penanggulangan untuk mengubah pergerakan per-jam menjadi satuan mobil penumpang (smp), besarnya emp berdasarkan hasil penelitian yang dapat dilihat pada Tabel 1 sebagai berikut:
Tabel 1. Faktor Ekivalen Mobil Penumpang

\begin{tabular}{lccc}
\hline \multirow{2}{*}{ Jenis Kendaraan } & \multicolumn{2}{c}{ Emp Untuk Tiap Pendekat } \\
\cline { 2 - 3 } & Terlindungi & Terlawan \\
\hline $\begin{array}{l}\text { Kendaraan } \\
(\mathrm{LV})\end{array}$ & Ringan & 1.0 & 1.0 \\
$\begin{array}{l}\text { Kendaraan } \\
(\mathrm{HV})\end{array}$ & Berat & 1.3 & 1.3 \\
$\begin{array}{l}\text { Sepeda } \\
(\mathrm{MC})\end{array}$ & Motor & 0.2 & 0.4 \\
\hline
\end{tabular}

Sumber: MKJI, 1997

Contoh rumus:

$\mathrm{Q}=\mathrm{QLV}+\mathrm{QHV} \mathrm{x}$ empHV + QMC $\mathrm{x}$ empMC...

Dimana:

$\mathrm{Q}=$ Arus lalulintas

QLV = Arus lalulintas kendaraan ringan

$\mathrm{QHV}=$ Arus lalulintas kendaraan berat

QMC = Arus lalulintas sepeda motor

empHV $=$ Ekivalen mobil penumpang kendaraan berat

empMC $=$ Ekivalen mobil penumpang sepeda motor

\section{Kapasitas (C)}

kapasitas suatu ruas jalan ialah jumlah kendaraan maksimum yang memiliki kemungkinan yang cukup untuk melewati ruas jalan tersebut (dalam satu atau pun kedua arah) dalam jangka waktu tertentu. Nilai dari kapasitas dapat dihitung menggunakan dua persamaan 2.4 dan 2.5 dibawah ini.

$\mathrm{C}=\mathrm{S} \times \mathrm{g} / \mathrm{c} \ldots \ldots \ldots \ldots \ldots$

Keterangan :

$\mathrm{C}=$ kapasitas $(\mathrm{smp} / \mathrm{jam})$

$\mathrm{S} \quad=$ Arus Jenuh $(\mathrm{smp} / \mathrm{jam})$

g = Waktu hijau (det)

$\mathrm{c} \quad=$ Waktu siklus hijau

\section{Derajat Kejenuhan}

Derajat kejenuhan (DS) didefinisikan sebagai rasio arus lalulintas terhadap kapasitas, yang digunakan sebagai factor utama dalam penentuan tingkat kinerja simpang dan segmen jalan. Nilai DS menunjukkan apakah segmen jalan tersebut mempunyai masalah kapasitas atau tidak. Untuk menghitung derahat kejenuhan pada suatu ruas jalan perkotaan mengunakan rumus (MKJI, 1997) sebagai berikut:

$D S=Q / C$

Dimana :

$\mathrm{DS}=$ Derajat kejenuhan

$\mathrm{Q}=$ Arus maksimum (smp/jam)

$\mathrm{C}=$ Kapasitas (smp/jam) 


\section{Arus Jenuh}

Menentukan Arus dasar (So) Arus jenuh merupakan arus maksimum pada mulut persimpangan jika lampu lalulintas terus menyala hijau. (MKJI, 1997).

So $=600 \times \mathrm{WA}$

Dimana :

So $=$ Arus Dasar

$\mathrm{WA}=$ Lebar Pendekat

Nilai Arus (S) Dinyatakan sebagai hasil pekalian arus jenuh dasar (So) yaitu arus jenuh pada kondisi standar, dengan faktor penyesuaian (F) untuk penyimpagan dari kondisi eksisting, dari sekumpulan kondisi-kondisi (ideal) yang telah ditentukan sebelumnya (MKJI, 1997).

$\mathrm{S}=\mathrm{S}_{0} \times \mathrm{F}_{\mathrm{SF}} \times \mathrm{F}_{\mathrm{CS}} \times \mathrm{F}_{\mathrm{G}} \times \mathrm{F}_{\mathrm{P}} \times \mathrm{F}_{\mathrm{RT}} \times \mathrm{F}_{\mathrm{LT}}$

Dimana :

$\mathrm{S}=$ Nilai arus

$\mathrm{S}_{0}=$ Arus dasar

$\mathrm{F}_{\mathrm{SF}}=$ Hambatan samping dan kendaraan tak bermotor

$\mathrm{F}_{\mathrm{CS}}=$ Penyesuaian ukuran kota

$\mathrm{F}_{\mathrm{G}}=$ Kelandaian

$\mathrm{F}_{\mathrm{P}}=$ Jarak Antara garis henti dan kendaraan yang diparkir pertama $(\mathrm{m})$

$\mathrm{F}_{\mathrm{RT}}=$ Penyesuaian belok kanan

$\mathrm{F}_{\mathrm{LT}}=$ Penyesuaian belok kiri

\section{Panjang Antrian}

Untuk menghitung jumlah antrian yang tersisa dari fase hijau sebelumnya digunakan hasil perhitungan derajat kejenuhan yang tersisa dari fase hijau sebelumnya (MKJI, 1997).

Untuk DS > 0.5 :

$$
N Q 1=0.25 \times C \times\left[\sqrt{(D S-1)^{2}+\frac{\left.8 x^{(D S}-0.5\right)}{c}}\right] \ldots
$$

Untuk DS $<0.5$ atau DS $=0.5 ; \mathrm{NQ}_{1}=0$

Dimana :

$\mathrm{NQ}_{1}=$ jumlah smp yang tersedia dari fase hijau sebelumnya

DS $=$ derajat kejenuhan

$\mathrm{C}=$ kapasitas $(\mathrm{smp} / \mathrm{jam})=$ arus jenuh dikalikan rasio hijau (SxGR)

Jumlah antrian smp yang datang selama fase merah $\left(\mathrm{NQ}_{2}\right)$

Dimana:

$$
\mathrm{NQ}_{2}=\mathrm{c} \times \frac{1-G R}{1-G R \times D S} \times \frac{Q}{3600} \ldots
$$

$\mathrm{NQ}_{2}=$ jumlah smp yang tersedia dari fase merah

$\mathrm{DS}=$ derajat kejenuhan

$\mathrm{GR}=$ rasio hijau $(\mathrm{g} / \mathrm{c})$

$\mathrm{c}=$ waktu siklus

$\mathrm{Q}_{\text {masuk }}=$ arus lalulintas pada tempat masuk di luar
LTOR (smp/jam)

Jumlah kendaraan antri

$$
\mathrm{NQ}=\mathrm{NQ}_{1}+\mathrm{NQ}_{2}
$$

Panjang antrian (QL) dengan mangalikan $\mathrm{NQ}_{\max }$ dengan luas rata-rata yang dipergunakan persmp $\left(20 \mathrm{~m}_{2}\right)$ kemudian bagilah dengan lebar masuknya

$$
\mathrm{QL}=\frac{\mathrm{NQ \operatorname {max } x 2 0}}{W \operatorname{masuk}} \ldots \ldots \ldots
$$

\section{Kendaraan Berhenti}

Angka henti (NS) masing-masing pendekat yang didefinisikan sebagai jumlah rata-rata berhenti per smp. NS ialah fungsi dari NQ dibagi dengan waktu siklus (MKJI, 1997).

$\mathrm{NS}=0.9 \times \frac{\mathbb{N Q}}{Q \times C} \times 3600 \ldots \ldots \ldots . .$.

Dimana :

$\mathrm{c}=$ waktu siklus

$\mathrm{Q}=$ arus lalulintas

Jumlah kendaraan terhenti $\mathrm{N}_{\mathrm{SV}}$ masing-masing pendekat

$\mathrm{N}_{\mathrm{SV}}=\mathrm{Q} \times \mathrm{NS}(\mathrm{smp} / \mathrm{jam}) \ldots \ldots \ldots$

Angka henti seluruh simpang dengan cara membagi jumlah kendaraan terhenti pada seluruh pendekat dengan arus simpang total $\mathrm{Q}$ dalam $\mathrm{kend} / \mathrm{jam}$.

$\mathrm{NS}_{\text {tot }}=\frac{\sum \mathrm{NSV}}{Q \text { total }} \ldots \ldots \ldots \ldots \ldots$

\section{Tundaan (delay)}

Tundaan lalulintas rata-rata setiap pendekat (DT) akibat pengaruh timbal balik dengan gerakan-gerakan lainnya pada simpang.

$$
\mathrm{DT}=\mathrm{c} \times \mathrm{A} \times \frac{\mathrm{NQ} 1 \times 3600}{c}
$$

Dimana :

$\mathrm{DT}=$ tundaan lalulintas rata-rata $(\operatorname{det} / \mathrm{smp})$

$\mathrm{C}=$ waktu siklus yang disesuaikan (det) $0.5 \times[1-G R]$

$\mathrm{A}=[1-G R \times D S)$

$\mathrm{GR}=$ rasio hijau $(\mathrm{g} / \mathrm{c})$

$\mathrm{DS}=$ derajat kejenuhan

$\mathrm{NQ}_{1}=$ jumlah smp yang tersisa dari fase hijau sebelumnya

$\mathrm{C}=$ kapasitas $\quad(\mathrm{smp} / \mathrm{jam}) 2$.

Tundaan geometrik rata-rata masing-masing pendekat (DG) akibat perlambatan dan percepatan ketika menunggu giliran pada suatu simpang dan/atau ketika dihentikan oleh lampu merah

$\mathrm{DG}_{\mathrm{j}}=\left(1-\mathrm{P}_{\mathrm{Sv}}\right) \times \mathrm{P}_{\mathrm{T}}$ x $6+\left(\mathrm{P}_{\mathrm{Sv}} \mathrm{x} 4\right) \ldots \ldots \ldots$

Dimana:

$\mathrm{DG}_{\mathrm{j}}=$ tundaan geometrik rata-rata untuk pendekat $\mathrm{j}$ (det/smp)

$\mathrm{P}_{\mathrm{SV}}=$ rasio kendaraan terhenti pada pendekat 
$\mathrm{P}_{\mathrm{T}}=$ rasio kendaraan berbelok

Tundaan rata-rata untuk seluruh simpang $\left(D_{1}\right)$ diperoleh dengan membagi jumlah nilai tundaan dengan arus total (Qtotal) dalam smp/jam

$$
D 1=\frac{\sum(Q x D 1)}{\text { Qtotal }}
$$

\section{Kinerja Ruas Jalan}

Menurut buku Highway Capacity Manual, pada dasarnya tingkat pelayanan suatu jalan tergantung pada arus lalulintas. Hal ini berkaitan dengan kecepatan operasi atau fasilitas jalan yang tergantung pada perbandingan antar kapasitas dan arus. Klasifikasi tingkat pelayanan jalan berdasarkan kapasitas dan arus ialah sebagai berikut.

Tabel 2. Klasifikasi Tingkat Pelayanan Jalan

\begin{tabular}{|c|c|c|}
\hline $\begin{array}{l}\text { Tingkat } \\
\text { Pelayanan }\end{array}$ & $\begin{array}{l}\text { Derajat } \\
\text { Kejenuhan } \\
\text { (DS) }\end{array}$ & Keterangan \\
\hline A & $0,00-0,20$ & Arus Bebas, kecepatan bebas \\
\hline B & $0,20-0,44$ & $\begin{array}{l}\text { Arus stabil, kecepatan mulai } \\
\text { terbatas }\end{array}$ \\
\hline $\mathrm{C}$ & $0,45-0,74$ & $\begin{array}{l}\text { Arus stabil, tetapi kecepatan } \\
\text { dan gerak kendaraan } \\
\text { dikendalikan }\end{array}$ \\
\hline $\mathrm{D}$ & $0,75-0,84$ & $\begin{array}{l}\text { Arus tidak stabil, kecepatan } \\
\text { menurun }\end{array}$ \\
\hline $\mathrm{E}$ & $0,85-1,00$ & $\begin{array}{l}\text { Arus stabil, kendaraan } \\
\text { tersendat }\end{array}$ \\
\hline $\mathrm{F}$ & $\geq 1,00$ & $\begin{array}{l}\text { Arus terhambat, kecepatan } \\
\text { rendah }\end{array}$ \\
\hline
\end{tabular}

Sumber : MKJI, 1997

\section{Sistem Satu Arah}

Sistem satu arah ialah hasil dari rekayasa lalulintas yang dilakukan dengan mengubah jalan dua arah menjadi satu arah yang berfungsi untuk meningkatkan keselamatan dan kapasitas jalan.

Kelebihan sistem satu arah, diantaranya :

1. Menambah kapasitas dan Antara simpang jalan distribusi lalulintas menjadi lebih baik.

2. Mengurangi jumlah konflik di persimpangan serta memudahkan pengaturan koordinasi sinyal lampu lalulintas.

3. Mengurangi kecelakaan lalulintas, walaupun demikian fasilitas menjadi bertambah mengingat kecepatan kendaraan meningkat.

4. Meningkatan kecepatan rata-rata kendaraan pada sistem jaringan jalan, walaupun demikian tidak berarti mempercepat waktu perjalanan.

5. Memungkinkan terjadinya peningkatan ekonomi/pendapatan wilayah, yang semulanya ialah kawasan yang tenang menjadi ramai.

6. Membaiknya kondisi parkir di tepi trotoar dan berkurangnya gangguan pemberhentian angkutan umum, dan kendaraan sedang melakukan bongkar muat.

Kekurangan sistem satu arah, diantaranya :

1. Dapat menyebabkan waktu perjalanan menjadi lebih lama karena harus berputar.

2. Memungkinkan fasilitas bertambah akibat kecepatan kendaraan menjadi lebih tinggi.

3. Menyulitkan angkutan umum apabila tidak disediakan lajur khusus yang berlawanan arus.

4. Menyulitkan masyarakat yang tidak terbiasa berpergian ke daerah tersebut karena rute menjadi berputar-putar

\section{METODE}

\section{Umum}

Dalam memperoleh informasi arus lalulintas perlu dilakukan survei untuk memperoleh data arus lalulintas yang representatif. Arus lalulintas dipengaruhi oleh banyak faktor seperti waktu, musim (musim hujan atau musim kemarau) atau hari raya keagamaan, hari survei (hari kerja), pusat kegiatan, daerah pemukiman atau daerah wisata, dan jenis kendaraan lalulintas (klasifikasi kendaraan).

Pada penelitian ini metode yang dipilih ialah metode survei manual yang secara langsung menghitung arus lalulintas pada ruas jalan tersebut dengan menggunakan surveyor. Surveyor ditempatkan pada setiap lengan di persimpangan untuk menentukan volume dari setiap pergerakan. Kendaraan dibagi menjadi beberapa kelompok untuk mendapatkan gambaran lengkap arus lalulintas dan seberapa besar pengaruhnya terhadap kapasitas jalan, diantaranya ialah sebagai berikut:

$$
\begin{array}{ll}
1 & =\text { Sepeda motor, scoter } \\
2 & =\text { Sedan, jeep, station wagon } \\
3 & =\text { Opelet, mikrilet } \\
4 & =\text { Pickup, box } \\
5 \mathrm{a} & =\text { Bus kecil } \\
5 \mathrm{~b} & =\text { Bus Besar } \\
6 & =\text { Mobil truk } 2 \text { sumbu } \\
7 \mathrm{a} & =\text { Mobil truk } 3 \text { sumbu } \\
7 \mathrm{~b} & =\text { Mobil gandengan } \\
7 \mathrm{c} & =\text { Mobil tempelan } \\
8 & =\text { kendaraan tidak bermotor }
\end{array}
$$

\section{Lokasi dan Waktu Penelitian}

Lokasi penelitian ini di lakukan di simpang empat Rembiga yang berada di jalan Adi Sucipto dengan Jalur Pendekat yaitu Jln. Jend. Sudirman dan Jln. 
Dr. Soetomo dengan Jalur Pendekat yaitu Jln. Dr. Wahidin, dimana dua jalan tersebut merupkan daerah komersial dengan volume lalulintas yang padat dan sering mengalami antrian yang panjang. Simpang empat Rembiga Kota Mataram yang merupakan pertemuan dari ruas jalan Kota Mataram dari arah selatan dan dari arah utara menuju ke Gunungsari Lombok Barat yang dipadati oleh pertokoan dan warung kuliner khas daerah rembiga, sedangkan dari arah timur ke barat tembus jalan Adi Sucipto yang juga merupakan pusat perkantoran, ruko dan warung kuliner khas lombok yang selalu dipadati oleh pengunjung. waktu penelitian diambil dua hari dalam senggang waktu satu minggu yakni pada hari senin dan rabu saat jam-jam puncak pagi pukul 07.00-09.00 WITA, siang pukul 12.00-14.00 WITA, dan sore pukul 16.00- 18.00 WITA. Survei pertamakali dilakukan pada tanggal 6 Maret 2021 untuk mengambil data geometri, dan pengambilan data LHR pada hari senin dan rabu tanggal $22 \& 24$ Maret 2021. Lokasi penelitian yakni simpang empat Rembiga, Kota Mataram pada Gambar 1 berikut.

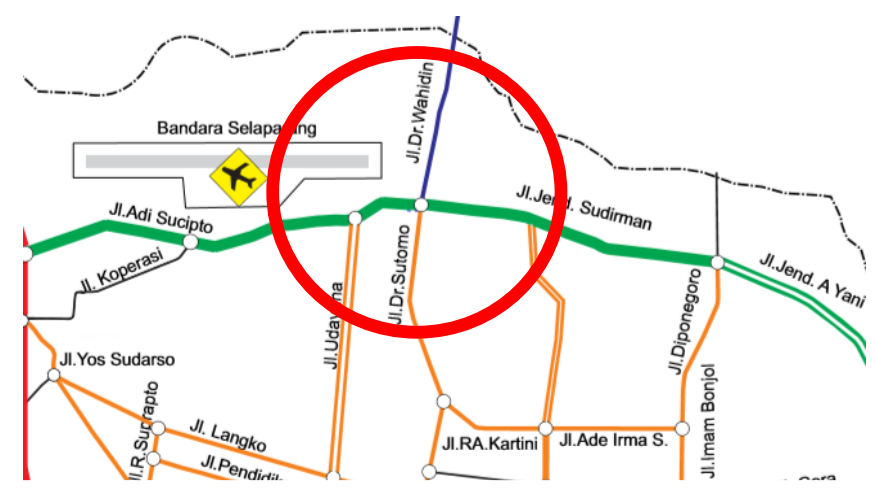

Gambar 1. Peta Lokasi Simpang Empat Rembiga Kota Mataram

Sumber: Google Earth, 2021



Gambar 2. Bagan Alir Penelitian 
Kajian Rekayasa Lalulintas .., Addinuri ${ }^{(1)}$, Titik Wahyuningsih ${ }^{(2)}$, Anwar Efendy $^{(3)}$

\section{HASIL DAN PEMBAHASAN}

Tabel 3. Kondisi Geometrik dan Lingkungan Persimpangan

\begin{tabular}{|c|c|c|c|c|}
\hline Kondisi Geometri & $\begin{array}{c}\text { Jalan Adi } \\
\text { sucipto (B) }\end{array}$ & $\begin{array}{c}\text { Jalan Jend. } \\
\text { Sudirman (T) }\end{array}$ & $\begin{array}{c}\text { Jalan Dr. } \\
\text { Wahidin (U) }\end{array}$ & $\begin{array}{c}\text { Jalan Dr. } \\
\text { Soetomo (S) }\end{array}$ \\
\hline Jumlah Jalur/arah & 2/2UD & 2/2UD & 2/2UD & 2/2UD \\
\hline Lebar Jalur Jalan & 13,7 & 17,6 & 9,7 & 16,3 \\
\hline Media Jalan & Tidak Ada & Tidak Ada & Tidak Ada & Tidak Ada \\
\hline Tipe Lingkungan & Komersial & Komersial & Komersial & Komersial \\
\hline Lebar Pendekat (LE) & 7,8 & 11,6 & 4,4 & 8,7 \\
\hline Lebar Masuk (LM) & 5,1 & 6,7 & 4,4 & 5,6 \\
\hline Belok Kiri lagsung $\quad$ (BKiJT) & 2,7 & 4,9 & - & 3,1 \\
\hline Lebar Keluar (Lk) & 6 & 5,9 & 5,5 & 3,1 \\
\hline
\end{tabular}

\section{Kondisi Geometrik dan Lingkungan Persimpangan}

Hasil survey yang dilakukan di lokasi yakni simpang empat Rembiga, kondisi lingkungan dan geometrik pada simpang empat Rembiga Kota Mataram yang telah dilakukan dengan pengukuran langsung secara manual serta pengamatan visual, maka data yang digunakan telah disajikan kedalam Tabel 3.

\section{Volume Arus Lalulintas}

Volume lalulintas harian rata-rata (LHR) pada Simpang Rembiga Kota Mataram, dilakukan dengan cara mencatat secara manual semua kendaraan yang melintasi garis henti pada persimpangan si setipa lengan dalam satu waktu pengamatan pada jam-jam sibuk yaitu: pagi (07.00-09.00), siang (11.30-13.30), dan sore (16.00-18.00) WIT dengan interval 15 mnit dilakukan pada hari jam sibuk (senin \& rabu). Data diakumulasikam untuk menentukan kapan jam puncak terjadi. Tabel 4 dan 5 merupakan data volume lalulintas jam puncak ruas pada hari senin dan hari rabu sebelum penerapan sistem satu arah

Berdasarkan hasil analisa jam puncak, dari hasil survey menunjukan volume lalulintas jam puncak terjadi pada hari senin pukul $16.45-17.45$, ini dikarenakan pada jam tersebut merupakan jam berakhirnya aktifitas perkantoran dan berakhirnya jam kerja waktu normal. Data volume kendaraan tertinggi didaptkan pada saat kondisi eksisting hari senin dapat dilihat pada Tabel 6 dan data volume kendaraan pada saat kondisi penerapan sistem satu arah dapat dilihat pada Tabel 7.
Tabel 4. Volume Lalulintas Jam Puncak Eksisting Hari : :Senin

Tanggal : 22 Maret 2021

\begin{tabular}{|c|c|c|c|c|c|c|}
\hline & \multirow{2}{*}{ Waktu } & \multicolumn{4}{|c|}{ Lengan } & \multirow{2}{*}{$\begin{array}{r}\text { Total } \\
\text { (kend) }\end{array}$} \\
\hline & & Barat & Timur & Selatan & Utara & \\
\hline \multirow{5}{*}{ 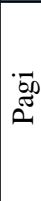 } & $07.00-08.00$ & 841 & 2209 & 1044 & 2057 & 6151 \\
\hline & $07.15-08.15$ & 922 & 2234 & 1064 & 2168 & 6388 \\
\hline & $07.30-08.30$ & 993 & 2184 & 1065 & 2122 & 6364 \\
\hline & $07.45-08.45$ & 1004 & 1983 & 1020 & 1921 & 5928 \\
\hline & $08.00-09.00$ & 975 & 1663 & 941 & 1647 & 5226 \\
\hline \multirow{5}{*}{ 每 } & $11.30-12.30$ & 1100 & 1500 & 1067 & 1253 & 4920 \\
\hline & $11.45-12.45$ & 1098 & 1570 & 1097 & 1240 & 5005 \\
\hline & $12.00-13.00$ & 1036 & 1563 & 1064 & 1241 & 4904 \\
\hline & $12.15-13.15$ & 931 & 1515 & 1045 & 1256 & 4747 \\
\hline & $12.30-13.30$ & 894 & 1449 & 1003 & 1205 & 4551 \\
\hline \multirow{5}{*}{ 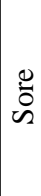 } & $16.00-17.00$ & 1349 & 1768 & 1338 & 1480 & 5935 \\
\hline & $16.15-17.15$ & 1486 & 2008 & 1447 & 1553 & 6494 \\
\hline & $16.30-17.30$ & 1529 & 2223 & 1566 & 1548 & 6866 \\
\hline & $16.45-17.45$ & 1475 & 2316 & 1596 & 1536 & 6923 \\
\hline & $17.00-18.00$ & 1385 & 2226 & 1551 & 1462 & 6624 \\
\hline
\end{tabular}

Tabel 5. Volume Lalulintas Jam Puncak Eksisting Hari : Rabu

Tanggal :23 Maret 2021

\begin{tabular}{|c|c|c|c|c|c|c|}
\hline \multirow{2}{*}{\multicolumn{2}{|c|}{ Vakt }} & \multicolumn{4}{|c|}{ Lengan } & \multirow{2}{*}{$\begin{array}{l}\text { Total } \\
\text { (kend) }\end{array}$} \\
\hline & & Barat & Timur & Selatan & Utara & \\
\hline \multirow{5}{*}{ 㱒 } & $07.00-08.00$ & 844 & 2152 & 975 & 2034 & 6005 \\
\hline & $07.15-08.15$ & 923 & 2160 & 985 & 2128 & 6196 \\
\hline & $07.30-08.30$ & 995 & 2104 & 995 & 2132 & 6226 \\
\hline & $07.45-08.45$ & 1004 & 1895 & 952 & 1917 & 5768 \\
\hline & $08.00-09.00$ & 990 & 1605 & 872 & 1638 & 5105 \\
\hline \multirow{5}{*}{ : } & $11.30-12.30$ & 1272 & 1463 & 1052 & 1071 & 4858 \\
\hline & $11.45-12.45$ & 1261 & 1503 & 1084 & 1033 & 4881 \\
\hline & $12.00-13.00$ & 1202 & 1493 & 1018 & 1026 & 4739 \\
\hline & $12.15-13.15$ & 1059 & 1441 & 977 & 1053 & 4530 \\
\hline & $12.30-13.30$ & 1040 & 1401 & 924 & 1109 & 4474 \\
\hline \multirow{5}{*}{ סे } & $16.00-17.00$ & 1233 & 1669 & 1326 & 1529 & 5757 \\
\hline & $16.15-17.15$ & 1363 & 1849 & 1397 & 1554 & 6163 \\
\hline & $16.30-17.30$ & 1400 & 2053 & 1534 & 1508 & 6495 \\
\hline & $16.45-17.45$ & 1349 & 2172 & 1545 & 1481 & 6547 \\
\hline & $17.00-18.00$ & 1321 & 2091 & 1498 & 1444 & 6354 \\
\hline
\end{tabular}


Tabel 6. Volume kendaraan jam puncak kondisi eksisting

\begin{tabular}{|c|c|c|c|c|c|}
\hline Nama simpang & \multicolumn{5}{|c|}{ : Simpang Empat Rembiga } \\
\hline Hari/Tanggal & \multicolumn{5}{|c|}{ : Senin, 22 Maret 2021} \\
\hline Ditangani oleh & \multicolumn{5}{|c|}{ : Addinuri } \\
\hline Periode & \multicolumn{5}{|c|}{ : Jam Puncak pukul $16.45-17-45$} \\
\hline \multirow{2}{*}{ Lengan Pendekat } & \multirow{2}{*}{ Arah } & $\mathrm{MC}$ & LV & $\mathrm{HV}$ & UM \\
\hline & & (kend) & (kend) & (kend) & (kend) \\
\hline Jalan Adi Sucipto & ST & 745 & 193 & 13 & 20 \\
\hline Lengan Barat & LT & 189 & 24 & 0 & 4 \\
\hline \multirow[t]{2}{*}{ (A) } & RT & 243 & 38 & 3 & 3 \\
\hline & Total & 1177 & 255 & 16 & 27 \\
\hline Jalan Jend. Sudirman & ST & 891 & 208 & 15 & 21 \\
\hline Lengan Timur & LT & 403 & 46 & 5 & 10 \\
\hline \multirow{2}{*}{ (B) } & RT & 555 & 142 & 17 & 3 \\
\hline & Total & 1849 & 396 & 37 & 34 \\
\hline Jalan Dr. Soetomo & ST & 646 & 84 & 0 & 6 \\
\hline Lengan Selatan & LT & 507 & 68 & 1 & 17 \\
\hline \multirow[t]{2}{*}{ (C) } & RT & 204 & 57 & 1 & 5 \\
\hline & Total & 1357 & 209 & 2 & 28 \\
\hline Jalan Dr. Wahidin & ST & 508 & 83 & 4 & 7 \\
\hline Lengan Utara & LT & 504 & 176 & 21 & 11 \\
\hline \multirow[t]{2}{*}{ (D) } & RT & 170 & 52 & 0 & 0 \\
\hline & Total & 1182 & 311 & 25 & 18 \\
\hline \multicolumn{2}{|l|}{ Jumlah } & 5565 & 1171 & 80 & 107 \\
\hline \multicolumn{2}{|l|}{ Q } & \multicolumn{4}{|c|}{6923} \\
\hline
\end{tabular}

Tabel 7. Volume kendaraan jam puncak kondisi sitem satu arah

\begin{tabular}{|c|c|c|c|c|c|}
\hline Nama simpang & \multicolumn{5}{|c|}{ Simpang Empat Rembiga } \\
\hline Hari/Tanggal & \multicolumn{5}{|c|}{ : Senin, 22 Maret 2021} \\
\hline Ditangani oleh & \multicolumn{5}{|c|}{ : Addinuri } \\
\hline Periode & \multicolumn{5}{|c|}{ Jam Puncak pukul 16.45 - 17-45 } \\
\hline \multirow{2}{*}{ Lengan Pendekat } & \multirow{2}{*}{ Arah } & $\mathrm{MC}$ & $\overline{L V}$ & HV & $\mathrm{UM}$ \\
\hline & & (kend) & (kend) & (kend) & (kend) \\
\hline Jalan Adi Sucipto & ST & 745 & 193 & 13 & 20 \\
\hline Lengan Barat & LT & 0 & 0 & 0 & 0 \\
\hline \multirow[t]{2}{*}{ (A) } & RT & 243 & 38 & 3 & 3 \\
\hline & Total & 988 & 231 & 16 & 23 \\
\hline Jalan Jend. Sudirman & ST & 1446 & 350 & 32 & 24 \\
\hline Lengan Timur & LT & 403 & 46 & 5 & 10 \\
\hline \multirow[t]{2}{*}{ (B) } & RT & 0 & 0 & 0 & 0 \\
\hline & Total & 1849 & 396 & 37 & 34 \\
\hline Jalan Dr. Soetomo & ST & 0 & 0 & 0 & 0 \\
\hline Lengan Selatan & LT & 1153 & 152 & 1 & 23 \\
\hline \multirow[t]{2}{*}{ (C) } & RT & 204 & 57 & 1 & 5 \\
\hline & Total & 1357 & 209 & 2 & 28 \\
\hline Jalan Dr. Wahidin & ST & 508 & 83 & 4 & 7 \\
\hline Lengan Utara & LT & 504 & 176 & 21 & 11 \\
\hline \multirow[t]{2}{*}{ (D) } & RT & 170 & 52 & 0 & 0 \\
\hline & Total & 1182 & 311 & 25 & 18 \\
\hline \multicolumn{2}{|l|}{ Jumlah } & 5376 & 1147 & 80 & 103 \\
\hline \multicolumn{2}{|l|}{$\mathrm{Q}$} & \multicolumn{4}{|c|}{6706} \\
\hline
\end{tabular}

Analisa Ruas Jalan Kondisi Eksisting

Analisa kinerja ruas simpang empat Rembiga Kota Mataram dilakukan dengan panduan MKJI 1997 berdasarkan data survei lalulintas dan geometri jalan pada kondisi eksisting. Perhitungan dilakukan dengan mempertimbangkan factor-faktor yang mempengaruhi seperti hambatan samping, klasifikasi jalan dan jumlah penduduk.

Kinerja ruas jalan dihitung dengan manggunakan perhitungan Manual Kapasitas Jalan Indonesi 1997 (MKJI 1997). Contoh ruas jalan dapat dilihat sepertu perhitungan dibawah ini :

1. Menentukan Arus dasar (So) Arus jenuh merupakan arus maksimum pada mulut persimpangan jika lampu lalulintas terus menyala hijau.

$$
\begin{aligned}
\text { So } & =600 \times \mathrm{WA} \\
\text { So } & =600 \times 4.4 \\
& =2640 \mathrm{smp} / \mathrm{jam}
\end{aligned}
$$

2. Nilai Arus (S) Dinyatakan sebagai hasil pekalian arus jenuh dasar (So) yaitu arus jenuh pada keadaan standar, dengan faktor penyesuaian (F) untuk penyimpagan dari kondisi sebenarnya, dari suatu kumpulan kondisi-kondisi (ideal) yang telah ditetapkan sebelumnya

$\mathrm{S}=\mathrm{S}_{0} \times \mathrm{F}_{\mathrm{SF}} \times \mathrm{F}_{\mathrm{CS}} \times \mathrm{F}_{\mathrm{G}} \times \mathrm{F}_{\mathrm{P}} \times \mathrm{F}_{\mathrm{RT}} \times \mathrm{F}_{\mathrm{LT}}$

$\mathrm{S}=2640 \times 0.92 \times 0.88 \times 1.00 \times 1.00 \times 1.04 \times$ $0.92=2045 \mathrm{smp} / \mathrm{jam}$

3. Arus lalulintas (Q) ialah jumlah kendaraan bermotor yang melalui titik tertentu persatuan waktu, dinyatakan dalam kendaraan perjam atau smp/jam. Menurut jenis dan arah pergerakan kendaraan yang melewati titik pengamatan (memasuki persimpangan). Dapat dilihat pada Tabel 1 untuk ketentun nilai Emp tiap jenis kendaraan.

$$
\begin{aligned}
& \mathrm{Q}=\mathrm{QLV}+\mathrm{QHV} \times \mathrm{empHV}+\mathrm{QMC} \times \mathrm{empMC} \\
& \mathrm{Q}=311+25 \times 1.3+1182 \times 0.2 \\
& =580 \mathrm{smp} / \mathrm{jam}
\end{aligned}
$$

4. Kapasitas (C) merupakan ruas jalan merupakan volume lalulintas maksimum yang dapat dipertahankan (tetap) pada suatu bagian Jalan dalam kondisi tertentu, dalam satuan kend/jam atau smp/jam

$$
\begin{aligned}
\mathrm{C} & =\mathrm{S} \times \mathrm{g} / \mathrm{c} \\
\mathrm{C} & =2045 \times 23 / 91 \\
& =511 \mathrm{smp} / \mathrm{jam}
\end{aligned}
$$

5. Derajat Kejenuhan (DS) Nilai DS menunjukkan apakah segmen jalan tersebut mempunyai masalah kapasitas atau tidak. Untuk menghitung derahat kejenuhan pada suatu ruas jalan perkotaan dengan rumus (MKJI, 1997) sebagai beriku :

$$
\begin{aligned}
\mathrm{DS} & =\mathrm{Q} / \mathrm{C} \\
\mathrm{DS} & =580 / 511 \\
& =1.13
\end{aligned}
$$

Nilai klasifikasi tingkat pelayanan dapat dilihat pada Tabel 2.

6. Panjang Antrian

a. Untuk menghitung jumlah antrian yang tersisa 
dari fase hijau $\left(\mathrm{NQ}_{1}\right)$ sebelumnya digunakan hasil perhitungan derajat kejenuhan yang tersisa dari fase hijau sebelumnya (MKJI, 1997).

Untuk DS > 0.5 :

$$
\begin{aligned}
& \mathrm{NQ}_{1}=0.25 \times C \times\left[\sqrt{(D S-1)^{2}+\frac{8 x(D S-0.5)}{6}}\right] \\
& \quad \mathrm{NQ}_{1} \\
& =0.25 \times 511 \times\left[\sqrt{(1.13-1)^{2}+\frac{22 x(1.12-0.5)}{511}}\right] \\
& \quad \mathrm{NQ}_{1}=37.51 \mathrm{~m}
\end{aligned}
$$

b. Jumlah antrian smp yang datang selama fase merah $\left(\mathrm{NQ}_{2}\right)$

$$
\begin{aligned}
& \mathrm{NQ}_{2}=\mathrm{c} \times \frac{1-G R}{1-G R \times D S} \times \frac{Q}{1600} \\
& \mathrm{NQ}_{2}=511 \times \frac{1-0.25}{1-0.25 \times 1.13} \times \frac{580}{3600} \\
& \mathrm{NQ}_{2}=15.32 \mathrm{~m} \\
& \text { c. Jumlah kendaraan antri (NQ) } \\
& \mathrm{NQ}=\mathrm{NQ}_{1}+\mathrm{NQ}_{2} \\
& \mathrm{NQ}=37.51+15.32 \\
& \mathrm{NQ}=52.83 \mathrm{~m}
\end{aligned}
$$

d. Panjang antrian (QL) dengan mangalikan $\mathrm{NQ}_{\max }$ dengan luas rata-rata yang dipergunakan persmp $\left(20 \mathrm{~m}_{2}\right)$ kemudian bagi dengan lebar masuk

$$
\begin{aligned}
& \mathrm{QL}=\frac{\frac{N \mathrm{Qmax} \times 20}{W \operatorname{masuk}}}{\frac{66 \times 20}{4.4}} \\
& \mathrm{QL}=\frac{\mathrm{m}}{\mathrm{QL}}=300 \mathrm{~m}
\end{aligned}
$$

\section{Pembahasan}

Dari hasil pengamatan di lapangan dan analisis perhitungan berdasarkan panduan MKJI 1997, didapat perhitungan kinerja ruas jalan sebelum diperlakukan sistem satu arah dengan kinerja ruas jalan setelah diberlakuakan sistem satu arah dengan parameter Kapasitas (C), Derajat Kejenuhan (DS) dan Tingkat Pelayanan (level of serfis) pada masing-masing ruas jalan yang diteliti. Rekapitulasi hasil perbandingan disajikan berupa tabel dan diagram seperti berikut :
Tabel 8. Perbandingan Kapasitas (C) Terhadap Tingkat Pelayanan Sebelum dan Sesudah Satu Arah

\begin{tabular}{lll}
\hline \multirow{2}{*}{ Ruas Jalan } & \multicolumn{2}{l}{ Kapasitas (C) (smp/jam) } \\
\cline { 2 - 3 } & Eksisting & Satu Arah \\
\hline Jalan Dr. Wahidin (U) & 511 & 1125 \\
Jalan Dr. Soetomo (S) & 397 & 720 \\
Jalan Jend. Sudirman (T) & 889 & 817 \\
Jalan Adi Sucipto (B) & 651 & 654 \\
\hline
\end{tabular}

Sumber: Pengolahan Data 2021

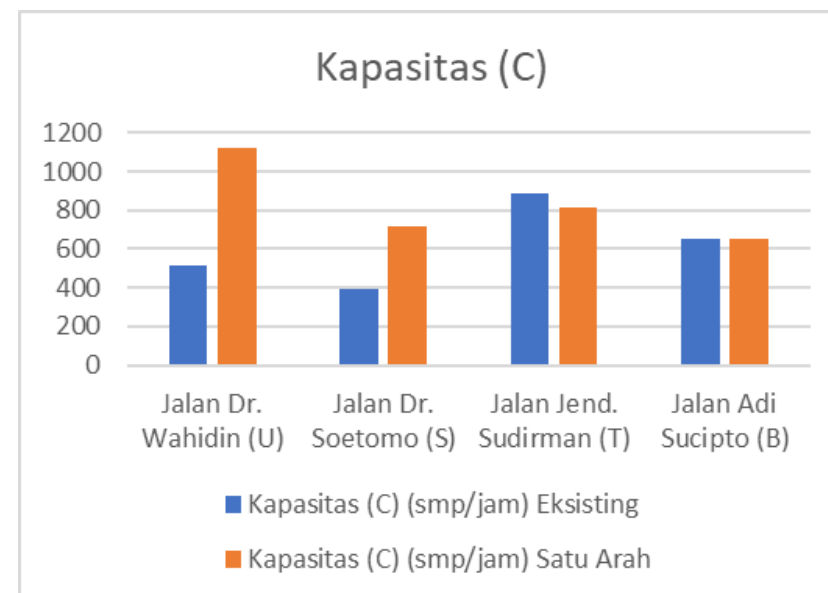

Gambar 3. Grafik Perbandingan Kapasitas (C) Terhadap Tingkat Pelayanan Sebelum dan Sesudah Satu Arah



Gambar 4. Grafik Perbandingan Perbandingan Derajat Kejenuhan \& Tingkat Pelayanan Terhadap Tingkat Pelayanan Sebelum dan Sesudah Satu Arah

Tabel 9. Perbandingan Derajat Kejenuhan \& Tingkat Pelayanan Terhadap Tingkat Pelayanan Sebelum dan Sesudah Satu Arah

Sumber: Pengolahan Data 2021

\begin{tabular}{llccc}
\hline \multirow{2}{*}{ Ruas Jalan } & \multicolumn{2}{c}{ Derajat Kejenuhan } & \multicolumn{2}{c}{ Tingkat Pelayanan } \\
& Eksisting & Satu Arah & Eksisting & Satu Arah \\
\hline Jalan Dr. Wahidin (U) & 1.13 & 0.52 & $\mathrm{~F}$ & $\mathrm{C}$ \\
Jalan Dr. Soetomo (S) & 0.79 & 0.14 & $\mathrm{D}$ & $\mathrm{A}$ \\
Jalan Jend. Sudirman (T) & 0.77 & 0.83 & $\mathrm{D}$ & $\mathrm{D}$ \\
Jalan Adi Sucipto (B) & 0.69 & 0.69 & $\mathrm{C}$ & $\mathrm{C}$ \\
\hline
\end{tabular}




\section{KESIMPULAN}

Terdapat beberapa hal yang dapat disimpulkan dari analisis dan perencanaan yang telah dilakukan yaitu sebagai berikut:

Dari hasil penelitian yang telah dilakukan pada simpang empat Rembiga Kota Mataram, didapatkan hasil analisa volume jam puncak maksimum, volume tertinggi pada hari senin berada pada lengan timur Jalan Jend. Sudirman dengan volume lalulintas jam puncak sebesar 681 smp/jam. kinerja kapasitas (C) ruas ini sebesar 889 smp/jam, derajar kejenuhan (DS) sebesar 0.77 dengan nilai tingkat pelayanan D. Pada ruas Jalan Dr. Wahidin dengan ruas lebar jalan yang paling kecil diantara keempat simpang mendapatkan volume lalulintas jam puncak sebesar 580 smp/jam, kinerja kapasitas (C) simpang 511 smp/jam dengan derajat kejenuhan (DS) 1.13 mendapatkan nilai tingkat pelayanan F. Jalan Dr Soetomo dilalui kendaran dengan volume lalulintas jam puncak sebesar $312 \mathrm{smp} / j a m$, kinerja kapasitas (C) ruas ini sebesar $398 \mathrm{smp} / \mathrm{jam}$, derajar kejenuhan (DS) sebesar 0.79 dengan nilai tingkat pelayanan D. Sedangkan pada ruas Jalan Adi Sucipto volume jam puncak maksimum sebasar $449 \mathrm{smp} / \mathrm{jam}$, kinerja kapasitas (C) ruas ini sebesar $651 \mathrm{smp} / \mathrm{jam}$, derajar kejenuhan (DS) sebesar 0.69 dengan nilai tingkat pelayanan $\mathrm{C}$.

Perbandingan dan tingkat kinerja pelayanan sangat terlihat jelas pada ruas Jalan Dr. Wahidin dimana saat kondisi eksisting didapat nilai derajat kejenuhan 1.13 yang berarti tingkat pelayanan pada ruas tersebut mendapatkan nilai $F$. setelah diterapkannya sistem satu arah derajat kejenuhan turun menjadi 0.52 dengan tingkat pelayanan berubah menjadi $\mathrm{C}$ dimana itu sangat berpengaruh pada pelayanan ruas jalan yang mengatasi kemacetan terjadi pada ruas jalan tersebut. Pada ruas Jalan Dr. Soetomo juga mempengaruhi hasil derajat kejenuhan pada kondisi eksisting sebesar 0.79 dengan tingkat pelayanan $\mathrm{D}$ berubah menjadi A dengan nilai derajat kejenuhan yang turun menjadi 0.14 setelah diterapkannya sitem satu arah pad ruas Jalan Dr. Wahidin. Sedangkan pada dua ruas Jalan Adi Sucipto dan Jalan Jend. Sudirman tidak mengalami perubahan tingkat pelayanan hanya saya pada ruas Jalan Jend. Sudirman mengalami kenaikan pada saat diterapkannya sistem satu arah sebesar 0.06 hal ini tidak terlalu berpengaruh terhadap tundaan kendaran dan panjangnya antrian.

\section{DAFTAR PUSTAKA}

Anonim, (1997). Manual Kapasitas Jalan Indonesia (MKJI). 1997. Direktorat Jendral Bina Marga. Departemen Pekerjaan Umum. Jakarta.

Hobbs, F.D., (1995). Perencanaan dan Teknik Lalulintas. Gadjah Mada University Press. Yogyakarta.

Menteri Perhubungan, (2015). Peraturan Menteri Perhubungan Nomor 96 Tahun 2015 Tentang Pedoman Pelaksanaan Kegiatan Manajemen Dan Rekayasa Lalulintas, Indonesia.

Munawar, A., (2004). Manajemen Lalulintas Perkotaan. Beta Offset. Yogyakarta

Romadhona, P. (2018). Solusi Jalan Satu Arah di Kota Yogyakarta. ejournal Universitas Dipenegoro. p-ISSN: 0852-1697, e-ISSN: 240-9919.

(http://ejournal.undip.ac.id/index.php/tehnik. Diakses 20 Juli 2019).

Widayanti, K. (2012). Studi Perbandingan Kinerja Sebelum dan Sesudah Perubahan Sistem Lalulintas Satu Arah Kota Jember. Tugas Akhir. Universitas Jember. Jember. 